\title{
MATHEMATICAL MODELING FOR DETERMINATION OF THE MAXIMUM MASS TRANSFER CAPACITY OF COWPEA BEANS
}

\author{
Hélio C. Franco Junior ${ }^{1}$, Romulo A. Morais ${ }^{1 *}$, Warley G. da Silva ${ }^{1}$, Maria O. S. Oliveira ${ }^{1}$, \\ Glêndara A. de S. Martins ${ }^{1}$
}

\author{
${ }^{1 *}$ Corresponding author. Federal University of Tocantins/ Palmas - TO, Brazil. \\ E-mail: romuloitallo2505@gmail.com | ORCID ID: https://orcid.org/0000-0003-3069-283X
}

\section{KEYWORDS}

Leguminous, Peleg model, hydration, beans.

\begin{abstract}
Cowpea beans are of great socioeconomic expression for the rural population in North and Northeastern Brazil. This legume is rich in essential nutrients and exhibits great resistance to water stress. However, for grain processing, it is fundamental to study legume behavior during the hydration process. This study aims to evaluate the mass transfer of different cowpea beans via mathematical modeling to determine the viability of hydration for commercialization as a canned product. Physical and chemical analyses of lipids and moisture were performed. The soaking process was performed in a water bath with distilled water at 30,40 , and $50{ }^{\circ} \mathrm{C}$. The mathematical model of Peleg presented satisfactory adjustments, with $\mathrm{R}^{2}$ values ranging between $99.78 \%$ and $99.99 \%$ and relative error (P) of $<3.74 \%$. In addition, the influence of binomial time/temperature was observed during hydration.
\end{abstract}

\section{INTRODUCTION}

Cowpea beans (Vigna unguiculata (L.) Walp.), well-known among rural Brazilian populations as "feijãode-corda" and "feijão macassar", can be cultivated in the Northern and Northeastern Brazil mainly for subsistence. Thus, it has become a product of great socioeconomic expression for these regions (Locatelli et al., 2014).

Cowpea beans have excellent nutritional composition, being a source of phenolic compounds, antioxidants (Araújo et al., 2018), proteins, carbohydrates, minerals, and dietary fiber, in addition to its low-fat content, for the needy population of the Northern and Northeast Brazil (Lima et al., 2014). It is primarily consumed in two ways, in the form of mature and immature grains with a high percentage of water ("green beans", with moisture contents ranging from 58 to $60 \%$ ) (Melo et al., 2017).

For bean processing, well-defined physical properties are required. Therefore, it is essential to use mathematical modeling to predict the behavior of bean material subjected to various processes (Resende \& Corrêa, 2007). According to Garcia et al. (2013), to model the grain hydration behavior, phenomenological and empirical mathematical models can be used to reduce time and product losses. Phenomenological models can explain the hydration mechanism with a theoretical foundation; however, they are complex in nature. In contrast, empirical models are less complex and easy to construct since they are obtained from mathematical correlations adjusted to the experimental data and not based on the laws of physics or mass transfer theories.

According to Marques et al. (2014), the characteristic behavior of agricultural products subjected to the hydration processes begins immediately after the grain contacts water, as absorption is instantaneous and occurs at an accelerated rate. This phase is called a transient. In the intermediate phase, the absorption rate is reduced, reaching equilibrium humidity. In the permanent phase, water absorption related to the grain equilibrium moisture occurs, where water loss and gain occur as the product approaches equilibrium moisture. Temperature affects the initial hydration speed, decreasing the rate as the water content of the product approaches equilibrium.

The proportion of grain water varies between $10 \%$ and $30 \%$ in relation to imbibition water (Carbonell et al., 2003; Ramos et al., 2005). According to Montanuci et al. (2014), the water absorption rate increases with increasing temperature and hydration time. Therefore, the water absorption rate is higher when the immersion temperature is closer to the seed gelatinization temperature.

In terms of the mass transfer of agricultural products, Peleg (1988) proposed an empirical model

\footnotetext{
${ }^{1}$ Federal University of Tocantins / Palmas - TO, Brazil.
} 
adjusted to literature data on water absorption in powdered milk and rice, obtaining correlation coefficients ranging from 0.95 to 0.99 .

In this context, the objective of this study was to determine the maximum mass transfer capacity of cowpea using the Peleg model, analyzing the viability of hydration for its use and commercialization as a canned product.

\section{MATERIAL AND METHODS}

\section{Characterization of raw materials}

Cowpea seeds (Vigna unguiculata (L.) Walp.) were purchased from producers in the state of Tocantins. The seeds were subsequently processed and the impurities were removed as well broken and abnormal grains.

After processing, the seeds were sent to the Process Modeling and Kinetics Laboratory, located at the Campus of the Federal University of Tocantins (UFT), Palmas, State of Tocantins. First, the sample humidity was determined using the standard thermostatic oven method at $105 \pm 1{ }^{\circ} \mathrm{C}$ for $24 \mathrm{~h}$ in triplicate (Brasil, 2009). Subsequently, lipid analysis was performed using the Soxhlet methodology in triplicate for each product variety.

\section{Experimental design}

The experimental design was completely randomized with 14 treatments and three replicates. The treatments were named as follows: BRS Millennium, BRS Itaim, BRS Potengi, BRS Pujante, BRS Novaera, BRS Cauamé, BRS Aracê, BRS Tumucumaque, BRS Juruá, BRS Rouxinol, BRS Marataoã, BRS Xiquexique, BRS Pajeú, and BRS Guariba.

\section{Water absorption}

For this process, $5 \mathrm{~g}$ of grain sample was soaked in $35 \mathrm{~mL}$ of distilled water (1:7 ratio). Hydration was performed at controlled temperatures of 30,40 , and $50{ }^{\circ} \mathrm{C}$ in a water bath until reaching water absorption equilibrium in triplicate for each temperature. During this process, the samples were weighed to track the absorption, removed from the beakers, and placed on a filter paper for $2 \mathrm{~min}$ to remove the surface water. After weighing, the samples were immersed again. To model cowpea hydration, the Peleg model (1988) described in [eq. (1)] was used:

$$
\mathrm{U}_{\mathrm{t}}=\mathrm{U}_{\mathrm{o}}+\frac{t}{\left(C_{1}+C_{2} t\right)}
$$

Where:

Ut is the water content at time $t$, (decimal b.s.);

$\mathrm{U} 0$ is the initial moisture content (decimal b.s.);

$\mathrm{t}$ is the soak time $(\mathrm{h})$;

$\mathrm{C} 1$ is the Peleg constant rate (h decimal b.s.-1), and

C2 is the Peleg constant capacity (decimal b.s.-1).

The degree of adjustment of the Peleg model and variation of the constants as a function of the imbibition temperature was verified by performing a regression analysis using the Gauss Newton method in Statistica $7.0^{\circledR}$ software.

To measure the degree of fit of the model, the significance of the regression coefficient was assessed by the Scott-Knott method, adopting a 1\% probability level. The magnitude of the coefficient of determination $\left(\mathrm{R}^{2}\right)$ of the relative mean error $(\mathrm{P})$ and standard error of the estimate (SE) using eqs (2) and (3), respectively:

$$
\begin{aligned}
& \mathrm{P}=\frac{100}{n} \sum \frac{|Y-\hat{\mathrm{Y}}|}{Y} \\
& \mathrm{SE}=\sqrt{\frac{\sum(Y-\hat{\mathrm{Y}})^{2}}{G L R}}
\end{aligned}
$$

Where:

$\mathrm{Y}$ is the experimentally observed value;

$\hat{Y}$ is the value estimated by the model;

$\mathrm{n}$ is the number of experimental observations, and

GLR is the degree of freedom of the model (number of model parameters minus the number of observations).

\section{Statistical analysis and averaging tests}

The lipid and moisture data were subjected to analysis of variance tests, and the means were compared using the Scott-Knott test at a 5\% significance level using the ASSISTAT version 7.7 program.

\section{RESULTS AND DISCUSSION}

Significant effects were detected for different varieties in terms of lipid and moisture characteristics (Table 1), indicating genetic variability. In addition, the coefficients of variation were low, indicating good experimental precision.

TABLE 1. Average ANOVA table values for the cowpea cultivars analyzed herein.

\begin{tabular}{cccc}
\hline Causes of Variation & \multicolumn{2}{c}{ Mean square of variables } \\
GL & Lipids & $0.71258^{*}$ \\
Treatments & 13 & $0.00059^{*}$ & $0.03646^{*}$ \\
Residue & 28 & $0.0003^{*}$ & - \\
Total & & - & 2.50 \\
Adjusted & 41 & 8.44 & 7.62294 \\
CV (\%) & & 0.06517 & \\
Overall Average & & & \\
\hline
\end{tabular}

* Significance at the $5 \%$ level determined by the $\mathrm{F}$ test. 
When analyzing the coefficient of variation $(\mathrm{CV})$ of the obtained data, in which $\mathrm{CV}$ values of $<10 \%$ are considered to be high precision. Low dispersion around the mean of the lipid and moisture analysis data as well as data homogeneity was verified. The physicochemical compositions of the cowpea varieties are presented in Table 2.

TABLE 2. Physicochemical characteristics of the cowpea varieties tested herein.

\begin{tabular}{|c|c|c|c|c|c|c|c|c|c|c|c|c|c|c|}
\hline & $\begin{array}{c}\text { BRS } \\
\text { Milênio }\end{array}$ & $\begin{array}{l}\text { BRS } \\
\text { Itaim }\end{array}$ & $\begin{array}{c}\text { BRS } \\
\text { Potengi }\end{array}$ & $\begin{array}{c}\text { BRS } \\
\text { Pujante }\end{array}$ & $\begin{array}{c}\text { BRS } \\
\text { Novaera }\end{array}$ & $\begin{array}{c}\text { BRS } \\
\text { Cauamé }\end{array}$ & $\begin{array}{c}\text { BRS } \\
\text { Aracê }\end{array}$ & $\begin{array}{l}\text { BRS } \\
\text { Tum. }\end{array}$ & $\begin{array}{l}\text { BRS } \\
\text { Juruá }\end{array}$ & $\begin{array}{l}\text { BRS } \\
\text { Roux. }\end{array}$ & $\begin{array}{l}\text { BRS } \\
\text { Mar. }\end{array}$ & $\begin{array}{l}\text { BRS } \\
\text { Xiq }\end{array}$ & $\begin{array}{l}\text { BRS } \\
\text { Pajeú }\end{array}$ & $\begin{array}{c}\text { BRS } \\
\text { Guariba }\end{array}$ \\
\hline Moisture & $\begin{array}{c}14.94 \mathrm{a} \pm \\
0.21\end{array}$ & $\begin{array}{c}12.87 \mathrm{c} \pm \\
0.22\end{array}$ & $\begin{array}{c}=12.60 \mathrm{~d} \pm \\
0.09\end{array}$ & $\begin{array}{c}13.90 \mathrm{~b} \pm \\
0.48\end{array}$ & $\begin{array}{c}11.84 \mathrm{e} \pm \\
0.04\end{array}$ & $\begin{array}{c}12.6 \mathrm{~d} \pm \\
0.34\end{array}$ & $\begin{array}{c}12.58 \mathrm{~d} \pm \\
0.30\end{array}$ & $\begin{array}{c}12.17 \mathrm{e} \pm \\
0.19\end{array}$ & $\begin{array}{c}14.48 \mathrm{a} \pm \\
0.41\end{array}$ & $\begin{array}{c} \pm 13.09 \mathrm{c} \pm \\
0.00\end{array}$ & $\begin{array}{c}=13.14 \mathrm{c} \pm \\
0.20\end{array}$ & $\begin{array}{c}14.01 \mathrm{~b} \pm \\
0.54\end{array}$ & $\begin{array}{c} \pm 13.17 \mathrm{c} \pm \\
0.12\end{array}$ & $\begin{array}{c}13.24 \mathrm{c} \pm \\
0.12\end{array}$ \\
\hline Lipids & $\begin{array}{c}2.29 \mathrm{a} \pm \\
0.22\end{array}$ & $\begin{array}{c}2.47 \mathrm{a} \pm \\
0.17\end{array}$ & $\begin{array}{c}1.88 \mathrm{~b} \pm \\
0.09\end{array}$ & $\begin{array}{c}1.86 \mathrm{~b} \pm \\
0.05\end{array}$ & $\begin{array}{c}1.83 b \pm \\
0.19\end{array}$ & $\begin{array}{c}2.44 \mathrm{a} \pm \\
0.33\end{array}$ & $\begin{array}{c}1.92 \mathrm{~b} \pm \\
0.26\end{array}$ & $\begin{array}{c}1.52 \mathrm{c} \pm \\
0.56\end{array}$ & $\begin{array}{c}2.19 \mathrm{a} \pm \\
0.34\end{array}$ & $\begin{array}{c}1.27 \mathrm{~d} \pm \\
0.12\end{array}$ & $\begin{array}{c}1.55 \mathrm{c} \pm \\
0.12\end{array}$ & $\begin{array}{c}1.22 \mathrm{~d} \pm \\
0.37\end{array}$ & $\begin{array}{c}1.94 \mathrm{~b} \pm \\
0.46\end{array}$ & $\begin{array}{c}1.52 \mathrm{c} \pm \\
0.17\end{array}$ \\
\hline
\end{tabular}

* BRS Tum. $=$ BRS Tumucumaque; BRS Roux = BRS Nightingale; BRS Mar. = BRS Marataoã; BRS Xiq. = BRS Xiquexique * Means followed by the same letters, on the same line, do not statistically differ at $5 \%$ significance as determined by the Scott-Knott test.

The water content observed in raw cowpea grains has been shown to vary between $8.58 \%$ and $10.41 \%$ (Pereira, 2014) and between $10.69 \%$ and $11.37 \%$ (Cavalcante et al., 2017). The highest water content was observed in the grains of cultivar BRS Milênio (14.94\%) and was statistically the same as the moisture content in the BRS Juruá grains. The lowest water content was observed in the grains $(11.84 \%)$ of cultivars BRS Nova era and BRS Tumucumaque.

According to the results presented in Table 2, the highest percentage of lipids was observed in the seeds of cultivar BRS Itaim (2.47\%), differing significantly from those of the BRS Milênio, BRS Cauamé, and BRS Juruá cultivars. The lowest percentage of lipids was found in the BRS Xiquexique cultivar (1.27\%), similar to that of BRS Rouxinol.

Cavalcante et al. (2017) and Mello et al. (2017) studied the chemical composition of raw cowpea cultivars and reported low lipid contents ranging from 1.30 to 2.18 $\mathrm{g} / 100 \mathrm{~g}^{-1}$. This reduced lipid content can be considered a disadvantage in terms of nutritional value, due to the fatty acids, and particularly the substantial amount of unsaturated fatty acids, present in beans that are essential to human health (Reyes-Moreno et al., 1993). In contrast, Carvalho et al. (2012) studied 30 Brazilian cowpea genotypes and showed fluctuations in the lipid percentage ranging from 1.0 to $4.60 / 100 \mathrm{~g}^{-1}$.

In addition, the BRS Cauamé and BRS Tumucumaque genotypes showed the best nutritional quality. The technological and nutritional qualities of beans are determined in part by the genotype and are influenced by environmental conditions during plant and seed development, including climate, cultivation practices, post-harvest technologies, storage conditions, and process technology. According to Shellie \& Hosfield (1991), the genotypes are responsible for $52 \%$ of the variation in water absorption and $25 \%$ in the required cooking time.

\section{Mathematical modeling of the absorption process}

The coefficients of determination, relative average error, and standard error of the Peleg model estimate, adjusted during the hydration of cowpea beans at 30, 40, and $50{ }^{\circ} \mathrm{C}$, are listed in Table 3 .

From the data presented in Table 3, coefficients of determination of $>99 \%$ were obtained, indicating good model adjustment to the experimental data (Lisbôa et al., 2015). In addition, low standard errors of the estimate and relative average errors were obtained $(<3.24 \%)$, which according to Cunningham et al. (2007) indicates the applicability of the model as the values were all $<10 \%$. 
TABLE 3. Coefficients of determination $\left(\mathrm{R}^{2}\right)$, relative average errors $(\mathrm{P})$, and standard error of the Peleg model estimate (SE) adjusted during the hydration of the three cowpea varieties under different temperature conditions.

\begin{tabular}{|c|c|c|c|c|c|c|}
\hline Treatment & Temperature $\left({ }^{\circ} \mathrm{C}\right)$ & $\mathrm{C} 1$ & $\mathrm{C} 2$ & $\mathrm{R}^{2}(\%)$ & SE (decimal) & $\mathrm{P}(\%)$ \\
\hline \multirow{3}{*}{ BRS PUJANTE } & 30 & $0.6228 * *$ & $0.8672 * *$ & 99.977 & 0.0097 & 0.61 \\
\hline & 40 & $0.3182 * *$ & $0.8907 * *$ & 99.947 & 0.0153 & 0.89 \\
\hline & 50 & $0.2225^{* *}$ & $0.8684 * *$ & 99.979 & 0.0102 & 0.55 \\
\hline \multirow{3}{*}{ BRS POTENGI } & 30 & $0.7727 * *$ & $1.2822 * *$ & 99.982 & 0.0054 & 0.37 \\
\hline & 40 & $0.4409^{* *}$ & $1.3430 * *$ & 99.977 & 0.0076 & 0.57 \\
\hline & 50 & $0.0639 * *$ & $1.3361 * *$ & 99.954 & 0.0098 & 0.78 \\
\hline \multirow{3}{*}{ BRS JURUÁ } & 30 & $0.1494 * *$ & $0.8964 * *$ & 99.968 & 0.0113 & 0.56 \\
\hline & 40 & $0.1678 * *$ & $1.0279 * *$ & 99.783 & 0.0204 & 1.26 \\
\hline & 50 & $0.1234 * *$ & $1.0544 * *$ & 99.945 & 0.0150 & 0.85 \\
\hline \multirow{3}{*}{ BRS ROUXINOL } & 30 & $2.5361 * *$ & $0.9549 * *$ & 99.898 & 0.0138 & 1.27 \\
\hline & 40 & $3.3518 * *$ & $0.8372 * *$ & 99.811 & 0.0133 & 1.20 \\
\hline & 50 & $0.5060 * *$ & $0.9707 * *$ & 99.924 & 0.0150 & 1.01 \\
\hline \multirow{3}{*}{ BRS PAJEÚ } & 30 & $2.1799 * *$ & $0.9479 * *$ & 99.974 & 0.0072 & 0.62 \\
\hline & 40 & $1.0227 * *$ & $0.9038 * *$ & 99.998 & 0.0016 & 0.10 \\
\hline & 50 & $0.2622 * *$ & $0.9735^{* *}$ & 99.983 & 0.0080 & 0.50 \\
\hline \multirow{3}{*}{ BRS MARATOÃ } & 30 & $2.2241 * *$ & $0.6461 * *$ & 99.947 & 0.0143 & 0.89 \\
\hline & 40 & $0.5475^{* *}$ & $0.9463 * *$ & 99.930 & 0.0104 & 0.68 \\
\hline & 50 & $0.1003 * *$ & $1.0219 * *$ & 99.977 & 0.0093 & 0.57 \\
\hline \multirow{3}{*}{ BRS GUARIBA } & 30 & $0.4753 * *$ & $1.1142 * *$ & 99.862 & 0.0127 & 0.96 \\
\hline & 40 & $0.1591 * *$ & $1.2059 * *$ & 99.978 & 0.0049 & 0.36 \\
\hline & 50 & $0.0374 * *$ & $1.2730 * *$ & 99.990 & 0.0008 & 0.05 \\
\hline \multirow{3}{*}{ BRS TUMUCUMAQUE } & 30 & $0.3064 * *$ & $1.0749 * *$ & 99.970 & 0.0089 & 0.59 \\
\hline & 40 & $0.0792 * *$ & $1.0985 * *$ & 99.989 & 0.0218 & 1.58 \\
\hline & 50 & $0.0696^{* *}$ & $1.2244 * *$ & 99.999 & 0.0010 & 0.06 \\
\hline \multirow{3}{*}{ BRS XIQUEXIQUE } & 30 & $0.2619 * *$ & $1.0999 * *$ & 99.930 & 0.0134 & 0.86 \\
\hline & 40 & $0.0987 * *$ & $1.1399 * *$ & 99.986 & 0.0047 & 0.32 \\
\hline & 50 & $0.0899 * *$ & $1.2924 * *$ & 99.991 & 0.0029 & 0.21 \\
\hline \multirow{3}{*}{ BRS ITAIM } & 30 & $0.4397 * *$ & $1.2979 * *$ & 99.997 & 0.0024 & 0.17 \\
\hline & 40 & $0.2141 * *$ & $1.3341 * *$ & 99.976 & 0.0072 & 0.54 \\
\hline & 50 & $0.1756^{* *}$ & $1.3315^{* *}$ & 99.999 & 0.0018 & 0.12 \\
\hline \multirow{3}{*}{ BRS NOVAERA } & 30 & $0.7698 * *$ & $1.2929 * *$ & 99.994 & 0.0035 & 0.26 \\
\hline & 40 & $0.7303 * *$ & $1.4455^{* *}$ & 99.990 & 0.0039 & 0.28 \\
\hline & 50 & $0.3780 * *$ & $1.1061^{* *}$ & 99.943 & 0.0129 & 0.91 \\
\hline \multirow{3}{*}{ BRS MILENIO } & 30 & $0.6613 * *$ & $1.1806^{* *}$ & 99.991 & 0.0043 & 0.29 \\
\hline & 40 & $0.1161 * *$ & $1.3690 * *$ & 99.939 & 0.0114 & 0.86 \\
\hline & 50 & $0.0559 * *$ & $1.4080^{* *}$ & 99.972 & 0.0077 & 0.51 \\
\hline \multirow{3}{*}{ BRS CAUAMÉ } & 30 & $0.3169^{* *}$ & $1.0680 * *$ & 99.986 & 0.0061 & 0.42 \\
\hline & 40 & $0.1732 * *$ & $1.1189 * *$ & 99.963 & 0.0107 & 0.64 \\
\hline & 50 & $0.2424 * *$ & $1.0902 * *$ & 99.994 & 0.0049 & 0.29 \\
\hline \multirow{3}{*}{ BRS ARACÊ } & 30 & $0.3841 * *$ & $1.2546^{* *}$ & 99.906 & 0.0147 & 1.00 \\
\hline & 40 & $0.4811 * *$ & $1.6304 * *$ & 98.829 & 0.0424 & 3.74 \\
\hline & 50 & $0.0670 * *$ & $1.2682 * *$ & 99.981 & 0.0078 & 0.49 \\
\hline
\end{tabular}

** Significant at the $1 \%$ probability level by Scott-Knott. 
Lisbôa et al. (2015) showed that the constant C1 is related to the mass transfer rate and higher temperatures generally resulted in lower $\mathrm{C} 1$ values. Schoeninger et al. (2018) indicated that increased hydration water temperature accelerated the absorption process, contributing to higher diffusion coefficients.
However, different behavior was observed for some varieties due to fermentation of the grains and loss of cellular structure stability after hydration. Montanuci et al. (2013) highlighted that the difference between grains may be due to the alteration of the structures of each cultivar and variations in the chemical and physical properties of the grains.

TABLE 4. Average absorbed water content ( $\mathrm{g}$ ) in cowpea grains after hydration at three temperatures.

\begin{tabular}{cccc|cccc}
\hline \multirow{2}{*}{ Variety } & \multicolumn{3}{c|}{ Temperature $\left({ }^{\circ} \mathrm{C}\right)$} & \multirow{2}{*}{ Variety } & \multicolumn{3}{c}{ Temperature $\left({ }^{\circ} \mathrm{C}\right)$} \\
\cline { 2 - 4 } \cline { 2 - 3 } & 30 & 40 & 50 & & 30 & 40 & 50 \\
\hline BRS PUJANTE & $5,9695^{\mathrm{b}}$ & $5,9550^{\mathrm{b}}$ & $6,1649^{\mathrm{a}}$ & BRS TUMUCUMAQUE & $5,0515^{\mathrm{e}}$ & $5,2505^{\mathrm{d}}$ & $4,7984^{\mathrm{f}}$ \\
BRS POTENGI & $4,2825^{\mathrm{g}}$ & $3,5350^{\mathrm{h}}$ & $4,3595^{\mathrm{g}}$ & BRS XIQUEXIQUE & $5,0185^{\mathrm{e}}$ & $5,0555^{\mathrm{e}}$ & $4,7207^{\mathrm{f}}$ \\
BRS JURUÁ & $6,2960^{\mathrm{a}}$ & $5,8470^{\mathrm{b}}$ & $5,5678^{\mathrm{c}}$ & BRS ITAIM & $4,2320^{\mathrm{g}}$ & $4,3530^{\mathrm{g}}$ & $4,4226^{\mathrm{g}}$ \\
BRS ROUXINOL & $4,5550^{\mathrm{f}}$ & $4,7080^{\mathrm{f}}$ & $5,4399^{\mathrm{c}}$ & BRS NOVAERA & $4,1290^{\mathrm{g}}$ & $4,3690^{\mathrm{g}}$ & $4,8756^{\mathrm{e}}$ \\
BRS MARATAOÃ & $5,7010^{\mathrm{c}}$ & $5,6185^{\mathrm{c}}$ & $5,4631^{\mathrm{c}}$ & BRS MILENIO & $4,7420^{\mathrm{f}}$ & $4,2015^{\mathrm{g}}$ & $4,3585^{\mathrm{g}}$ \\
BRS PAJEÚ & $4,7895^{\mathrm{f}}$ & $5,5930^{\mathrm{c}}$ & $5,6198^{\mathrm{c}}$ & BRS CAUAMÉ & $5,1405^{\mathrm{d}}$ & $4,6300^{\mathrm{f}}$ & $5,0540^{\mathrm{e}}$ \\
BRS GUARIBA & $4,8955^{\mathrm{e}}$ & $4,7350^{\mathrm{f}}$ & $4,4704^{\mathrm{g}}$ & BRS ARACÊ & $4,4015^{\mathrm{g}}$ & $4,1875^{\mathrm{g}}$ & $4,5685^{\mathrm{f}}$ \\
\hline
\end{tabular}

Averages followed by the same lowercase letter in the same column are not statistically different as determined by the Scott-Knott test at a $1 \%$ probability.

Comparing the water contents of the cowpea cultivar grains at the three temperatures revealed a significant difference between averages at the 5\% probability level (Table 4). In particular, the cultivars BRS Juruá and BRS Pujante showed greater water absorption at 30,40 , and $50{ }^{\circ} \mathrm{C}$.

Shellie \& Hosfield (1991) found that the cultivar origin influences the water absorption by the plant, which is related to the temperature and precipitation of the native regions. The authors reported that the vegetables produced in dry and hot places showed greater water absorption capacities than those produced in cold and humid places. This was associated with the intrinsic factors of the vegetables related to the integument, including thickness, weight, adhesion to the cotyledons, elasticity, porosity, and colloidal properties.

Hydration at temperatures of $<60{ }^{\circ} \mathrm{C}$ allows the transfer of soluble compounds from the vegetable to hydration water (Kon, 1979). The temperatures evaluated herein allow maintenance of the nutritional quality of the final product and the internal pressure in the beans, which may be disrupted at high temperatures leading to the separation of cotyledons (Abu-Ghannam \& McKenna, 1997) leaving the beans cracked or broken.

\section{CONCLUSIONS}

Cowpea has a short shelf life and forms of processing that increase its stability are necessary to increase possible storage times. Canning is a promising alternative to achieve this goal, as demonstrated herein.

The lipid contents were in accordance with literature values, with differences between varieties resulting from differences in cultivar and cultivation conditions.

The Peleg model was adjusted satisfactorily to the obtained hydration data of cowpea, with high coefficients of determination $\left(\mathrm{R}^{2}>99.783 \%\right)$ and low relative average errors and standard deviations of the estimates.

The BRS Juruá and BRS Pujante cultivars showed higher water absorption at all temperatures evaluated herein, demonstrating the non-interference of temperature in the absorption.

Future studies regarding the total nutritional composition and anti-nutritional factors should be performed to ensure the stability of canned bean cultivars.

\section{REFERENCES}

Abu-Ghannam N, McKenna B (1997) Hydratation Kinetics of Red Beans (Phaseolus vulgaris L.). Journal of Food Science 62(3):520-523.

Araújo RSRM, Sampaio GR, Soares RAM, Silva CP, Araújo MAM, Arêas JAG (2018) Identification and quantification of phenolic compounds and antioxidant activity in cowpeas of brs xiquexique cultivar. Revista Caatinga 31(1):209-216.

Brasil. Ministério da Agricultura, Pecuária e Abastecimento (2009) Secretaria Nacional de Defesa Agropecuária. Regras para análises de sementes. Brasília, DF, $399 \mathrm{p}$.

Carbonell SAM, Carvalho CRL, Azevedo FJA, Sartori JA (2003) Qualidade tecnológica de grãos de genótipos de feijoeiro cultivados em diferentes ambientes. Bragantia 62(3):369-379.

Carvalho AFU, Sousa NM, Farias DF, Rocha-Bezerra LCB, Silva RMP, Viana MP, Gouveia ST, Sampaio SS, Sousa MB, Lima GPG, Morais SM, Barros CC, Freire Filho FR (2012) Nutritional ranking of 30 Brazilian genotypes of cowpeas including determination of antioxidant capacity and vitamins. Journal of Food Composition and Analysis 26(1):81-88. 
Cavalcante RBM, Araújo MAM, Rocha MM, Araújo RSRM (2017) Effect of thermal processing on chemical compositions, bioactive compounds, and antioxidant activities of cowpea cultivars. Revista Caatinga 30(4):1050-1058.

Cunningham SE, Mcminn WAM, Richardson PS (2007) Modelling water absorption of pasta during soaking. Journal of Food Engineering 82:600-607.

Garcia C (2005) Modelagem e Simulação de Processos Industriais e de Sistemas Eletromecânicos. v1. Edusp.

Kon S (1979) Effect of soaking temperature on cooking and nutritional quality of beans. Journal of Food Science 44(5):1329-1335.

Lima OM, Gomes FA, Mattar EPL, Ribeiro OAS, Ferreira JB (2014) Aspectos nutricionais de feijões crioulos cultivados na amazônica ocidental, Acre, Brasil. Enciclopédia Biosfera 10(19):163-175.

Lisbôa JF, Silva JN, Cavalcanti MT, Silva EM \& Gonçalves MC (2015) Analysis of hydration of grains of birdseed. Revista Brasileira de Engenharia Agricola e Ambiental 19(3):218-223.

Locatelli VER, Medeiros RD, Smiderle OJ, Albuquerque JAA, Araújo WF, Souza KTS (2014) Componentes de produção, produtividade e eficiência da irrigação do feijãocaupi no cerrado de Roraima. Revista Brasileira de Engenharia Agrícola e Ambiental 18(6):574-580.

Marques BC, Jorge LMDM, Jorge RMM (2014) Hydration kinetics, physicochemical composition, and textural changes of transgenic corn kernels of flint, semi-flint, and dent varieties. Food Science and Technology 34(1):88-93.

Melo NQC, Araújo RSRM, Araújo MAM, Rocha MM (2017) Chemical characterization of green grain before and after thermal processing in biofortified cowpea cultivars. Revista Ciência Agronômica 48(5 Especial):811-816.
Montanuci FD, Jorge LMM, Jorge RMM (2013) Kinetic, thermodynamic properties, and optimization of barley hydration. Food Science and Technology 33(4):690-698.

Montanuci FD, Perussello CA, Jorge LMM, Jorge RMM (2014) Experimental analysis and finite element simulation of the hydration process of barley grains. Journal of Food Engineering 131(1):44-49.

Peleg M (1988) An empirical model for the description of moisture sorption curves. Journal Food Engineering 52:1216-1219.

Pereira EJ (2014) Efeito do tratamento térmico sobre a bioacessibilidade de ferro e zinco em feijão-caupi. In Embrapa Agroindústria de Alimentos-Artigo em anais de congresso (ALICE). In: Congreso Iberoamericano de Ingeniería de Alimentos 2:239-245.

Ramos JEU, Lemos LB, Silva TRB (2005) Componentes da produção, produtividade de grãos e características tecnológicas de cultivares de feijão. Bragantia 64(1):75-82.

Resende O, Corrêa PC (2007) Modelagem matemática do processo de hidratação de sementes de feijão. Acta Scientiarum Agronomy 29(3):373-378.

Reyes-Moreno C, Paredes-López O, Gonzalez E (1993) Hard to-cook phenomenon in common beans: a review. CRC Critical Reviews in Food Science and Nutrition 33(3):227-286.

Schoeninger V, Bassinello PZ, Coelho SRM, Silva LB (2018) Industrialização e qualidade de feijões enlatados. Embrapa Arroz e Feijão-Artigo em periódico indexado (ALICE) 2(1):01-03.

Shellie KC, Hosfield GL (1991) Genotype x Envrionmental Effects on Food Quality of Common Bean: Resourceefficient Testing Procedures. Journal of American Society of Horticultural Science 116(4):732-736. 